Research Article

\title{
CRITICAL APPRAISAL OF MANAGEMENT PRACTICES IN NEPALESE GUAVA ORCHARDS
}

\author{
A. K. Shrestha \\ Institute of Agriculture and Animal Sciences, Rampur, Chitwan, Nepal \\ Email: arjun_sh@hotmail.com
}

\begin{abstract}
A survey was conducted to appraise the guava farming in Nepal with respect to the orchard management practices, cultivar status and major production constraints during July- December 2001. Guava plantation was extensively distributed throughout terai, inner terai and mid hill districts ranging in altitude from 115 masl to 1600 masl. Indian varieties dominated the guava plantation in Nepal although mix population of both improved and local cultivars was reported in majority of orchards. Preponderance of seedling origin guava plantation was noticed. The management practices were poor. Over $80 \%$ of the orchards received neither FYM nor chemical fertilizer. Similarly, more than $90 \%$ of the orchards were under rainfed condition. The peak period of flowering was reported during April/May followed by Feb/March that may extend up to June/July. As a consequence, the fruit availability period is mainly restricted to four months, i.e. July/ August to Oct/Nov. Most of the growers pointed out guava wilt as the main biotic constraint in guava production. The outcomes indicted the urgent need to adopt the effective control measures against the guava wilt malady to flourish guava enterprise in Nepal. Furthermore, off-season production of guava fruit has the great potential in Nepalese market.
\end{abstract}

Key words: cultivar, guava wilt, orchard, Psidium guajava

\section{INTRODUCTION}

Guava (Psidium guajava L.), popularly known as poor man's apple, is one of the most common fruit crops in Terai, inner Terai and hilly region of Nepal from the viewpoint of being high value, income generating, family nutrition improving and high yield potential crop. It is quite hardy, prolific bearer (90-350 kg fruits/ plant/year) and highly remunerative even without much care, hence, is favorite crop of the poor farmers. Among sub-tropical fruit crops, guava can be categorized as the $2^{\text {nd }}$ important fruit crop in Nepal only after orange. Further, if one compares the production of fruits grown in the hill districts of Nepal, guava is the $2^{\text {nd }}$ fruit crop (17329 t.) after orange (Ministry of Agriculture and Co-operatives, 2000). The domestic demand for guava is not being met it's production within the country; as a result, it is imported from foreign country. Currently, Nepal imports $85 \%$ of its fruit consumption (APP, 1995). In spite of its importance in the livelihood and upliftment of the economy of hill farmers, the production and productivity of the guava orchard have been declined due to the wilt problem throughout Nepal. This problem has been identified as an important biotic constraint (Gautam and Dhakal, 1993). The production and productivity of guava can only be improved if the wilt problem can be managed at desired level.

Sen and Verma (1954) reported that the soil conditions relating to nutrition and water are the factors that lay the groundwork for the wilt disease. Proper orchard sanitation and intercultural operation like timely application of adequate manure and plant protection measure enable the guava plants to withstand infection. A continuous observation on guava wilt at Rampur, Chitwan for 3 years indicated a varietal tolerance against this disease (Shrestha, 1998). Therefore, the present study was undertaken to assess the incidence of wilt disease in different guava growing pockets/districts of Nepal along with the cultivar status, cropping system, orchard size and management related aspects of guava cultivation.

\section{METHODOLOGY}

The present study was conducted during July - Dec 2001 and it involved a combination of methodologies such as mailing information and field survey. District Agriculture Development Office of all the 69 districts 
where guava was being cultivated were questioned via ordinary mail with respect to the major guava pockets, farms/nurseries, varietal status, and incidence of wilt in those respective districts. Based on the response/ reply of the concerned districts, agro-ecological similarity of various districts and market accessibility, altogether of 57 guava orchards and 7 nurseries of 23 districts in the hills and terai of Nepal were surveyed. During the survey period, semi structured questionnaire prepared by a multi-disciplinary team (comprising of pomologist, pathologist, entomologist, socioeconomist, soil analyst) regarding the production aspect, incidence of wilt disease and also the traditional techniques to mitigate the malady (if any) was filled up on the spot.

\section{RESULTS AND DISCUSSION}

\section{Occurrence}

Guava is a favorite fruit commodity among the fruit growers and consumers in Nepal. It was reported to be extensively distributed throughout the country except two districts of western mountain (viz. Manang and Mustang) and four districts of mid-western mountain consisting of Dolpa, Mugu, Humla and Jumla districts (MOAC, 2000). This fruit crop was observed cultivated in all the agro-ecological regions of Nepal ranging in altitude from 115 masl in Bara (terai) to 1600 masl in Terhathum (mountain) (Table 1). Earlier, Gautam and Dhakal (1993) reported that guava is grown across the hills of Nepal up to an elevation of 1500 masl while Bose and Mitra (1996) stated that this fruit crop could be grown from sea level to an altitude of 1515 masl. Yadava (1996) also mentioned that guava plants exceed the majority of tropical and sub-tropical fruits trees in adaptability and thrives well in both humid and dry climates between sea level and 2100 masl.

Table 1. Variation in altitude, soil texture and cropping system of guava orchards in Nepal

\begin{tabular}{|c|c|c|c|c|}
\hline SN & Survey district & Altitude (masl) & Texture of orchard soil & Cropping system \\
\hline 1 & Arghakhachi & 900 & Clay/Heavy & Intercrop \\
\hline 2 & Arghakhachi & 1000 & Sandy /Light & Intercrop \\
\hline 3 & Arghakhachi & 1000 & Loamy/Medium & Intercrop \\
\hline 4 & Arghakhachi & 1025 & Sandy /Light & Intercrop \\
\hline 5 & Arghakhachi & 1050 & Sandy /Light & Intercrop \\
\hline 6 & Arghakhachi & 1050 & Loamy/Medium & Intercrop \\
\hline 7 & Arghakhachi & 1050 & Sandy /Light & Intercrop \\
\hline 8 & Arghakhachi & 1100 & Clay/Heavy & Intercrop \\
\hline 9 & Arghakhachi & 1100 & Loamy/Medium & Intercrop \\
\hline 10 & Arghakhachi & 1100 & Loamy/Medium & Intercrop \\
\hline 11 & Bara & 115 & Loamy/Medium & Main \\
\hline 12 & Bara & 120 & Sandy /Light & Intercrop \\
\hline 13 & Chitwan & 300 & Loamy/Medium & Intercrop \\
\hline 14 & Chitwan & 450 & Clay/Heavy & Intercrop \\
\hline 15 & Chitwan & 600 & Sandy /Light & Intercrop \\
\hline 16 & Chitwan & 700 & Sandy / Light & Intercrop \\
\hline 17 & Chitwan & 750 & Sandy / Light & Intercrop \\
\hline 18 & Dadeldhura & 1300 & Loamy/Medium & Main \\
\hline 19 & Dadeldhura & 1400 & Loamy/Medium & Main \\
\hline 20 & Dadeldhura & 1450 & Loamy/Medium & Main \\
\hline 21 & Dhading & 740 & Sandy /Light & Main \\
\hline 22 & Dhading & 950 & Clay/Heavy & Intercrop \\
\hline 23 & Dhankuta & 1000 & Loamy/Medium & Intercrop \\
\hline 24 & Dhankuta & 1100 & Sandy /Light & Main \\
\hline 25 & Dhankuta & 1150 & Loamy/Medium & Intercrop \\
\hline 26 & Gorakha & 600 & Clay/Heavy & Intercrop \\
\hline 27 & Gorakha & 650 & Clay/Heavy & Main \\
\hline 28 & Gorakha & 750 & Clay/Heavy & Intercrop \\
\hline 29 & Gorakha & 800 & Loamy/Medium & Intercrop \\
\hline 30 & Gorakha & 1000 & Sandy /Light & Main \\
\hline
\end{tabular}




\begin{tabular}{|c|c|c|c|c|}
\hline 31 & Kapilvastu & 250 & Loamy/Medium & Intercrop \\
\hline 32 & Kaski & 1150 & Loamy/Medium & Intercrop \\
\hline 33 & Kaski & 1200 & Sandy/Light & Intercrop \\
\hline 34 & Kaski & 1200 & Loamy/Medium & Main \\
\hline 35 & Kaski & 1200 & Loamy/Medium & Main \\
\hline 36 & Kavre & 950 & Loamy/Medium & Main \\
\hline 37 & Kavre & 980 & Loamy/Medium & Main \\
\hline 38 & Lamjung & 700 & Clay/Heavy & Main \\
\hline 39 & Lamjung & 750 & Sandy/Light & Main \\
\hline 40 & Lamjung & 780 & Sandy/Light & Intercrop \\
\hline 41 & Lamjung & 800 & Sandy/Light & Main \\
\hline 42 & Lamjung & 810 & Loamy/Medium & Main \\
\hline 43 & Morang & 420 & Clay/Heavy & Intercrop \\
\hline 44 & Rautahat & 250 & Clay/Heavy & Intercrop \\
\hline 45 & Rupandehi & 240 & Clay/Heavy & Intercrop \\
\hline 46 & Syangja & 960 & Loamy/Medium & Intercrop \\
\hline 47 & Syangja & 1000 & Loamy/Medium & Intercrop \\
\hline 48 & Syangja & 1000 & Clay/Heavy & Intercrop \\
\hline 49 & Syangja & 1200 & Loamy/Medium & Main \\
\hline 50 & Tanahu & 500 & Loamy/Medium & Intercrop \\
\hline 51 & Tanahu & 500 & Loamy/Medium & Intercrop \\
\hline 52 & Tanahu & 700 & Clay/Heavy & Intercrop \\
\hline 53 & Tanahu & 720 & Loamy/Medium & Main \\
\hline 54 & Tanahu & 750 & Clay/Heavy & Intercrop \\
\hline 55 & Terhathum & 900 & Clay/Heavy & Intercrop \\
\hline 56 & Terhathum & 1000 & Clay/Heavy & Intercrop \\
\hline 57 & Terhathum & 1600 & Loamy/Medium & Main \\
\hline
\end{tabular}

\section{Cropping system, orchard size and orchard management practice}

Nepalese farming system has the tradition of growing at least few guava fruit plants in the homestead garden. However, guava was being increasingly cultivated in semi-commercial or commercial scale. Notwithstanding, in recent years, the semi-commercial/commercial guava plantation started declining primarily due to the wilt malady in Nepal. Majority of the guava growers were cultivating guava as the secondary/ intercrop in their fruit orchards while $37 \%$ of the guava orchards had the guava plantation as the main crop (Table 1). While assessing the lime and lemon production in Nepal. Dhakal et al. (2002) recorded that majority of fruit growers are growing these fruit crops as secondary crops.

It was observed that greater number of guava orchards had the population of less than 10 guava plants although the $31 \%$ of guava orchards had with more than 20 plants and $24 \%$ of the orchards with more than 50 plants per orchard (Figure 1). Small percentage of semi commercial and/or commercial scale of guava orchards may be due to the devastating influence of guava wilt disease in Nepal.

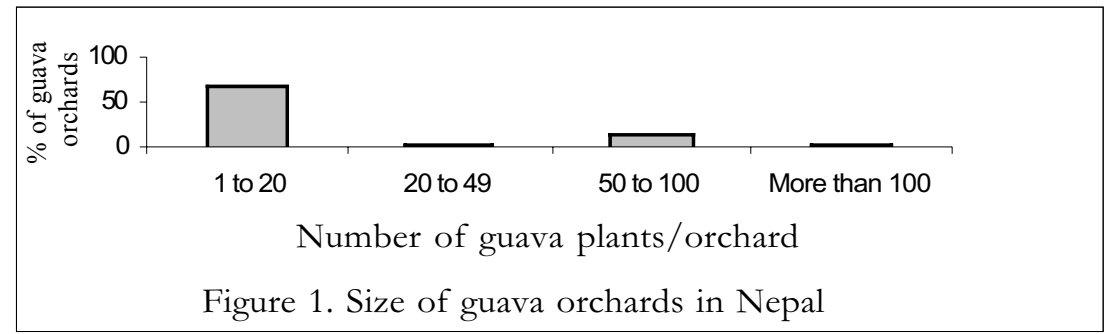

In Nepalese guava orchards, the orchard management practices, like manure and fertilizer application, and periodic irrigation of guava orchards was found poor. A large share $(81 \%)$ of the guava orchards received neither farmyard manure (FYM) nor chemical fertilizer (Figure 2). However, 14\% of the guava growers were 
applying only farmyard manure to their guava plants, whereas negligible proportion of guava orchards received the combination of FYM and chemical fertilizer. Dhakal et al. (2002) also observed very poor soil management practice in lime and lemon orchards.

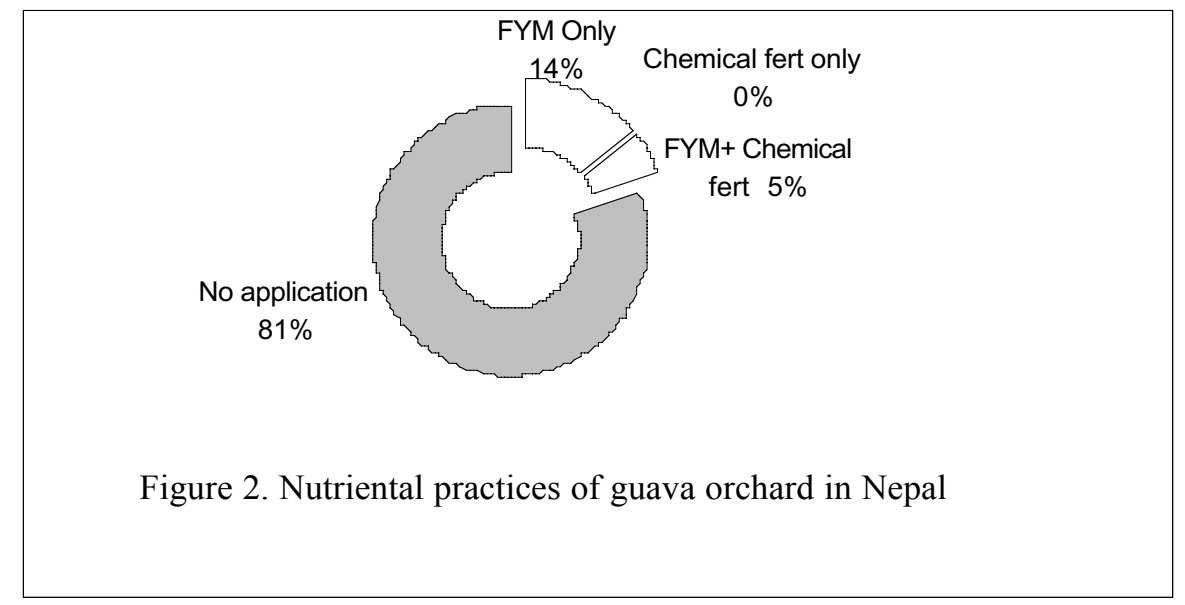

Regarding the provision of irrigation facility in the guava orchard, only $7 \%$ of the guava orchards had such assured supply of irrigation, while rest of orchards totally relied on natural precipitation for the supply of moisture in orchard. Most of the lime and lemon orchards were reported under rain fed condition by Dhakal et al. (2002). Singh (1969) also reported that in guava farming, irrigation is rarely done in actual practices.

\section{Planting material}

About half of the existing guava orchards in Nepal were of seedling origin although $30 \%$ of the orchards had plants of both the asexual and sexual origin (Figure 3). About a quarter of total guava orchards were composed of the vegetatively propagated (specifically layered) plants. Moreover, none of the guava growers planted grafted saplings in their orchards. The preponderance of sexually propagated guava plants might be due to the fact that guava can be easily propagated by seeds and also because most of the farmers aren't fully aware of other vegetative means of propagation. Yadava (1996) concealed that guava is generally propagated from seeds although it can be propagated by air layering, grafting and budding. Dhakal et al. (2002) also recorded that the existing lime and lemon orchards were mostly of seedling origin.

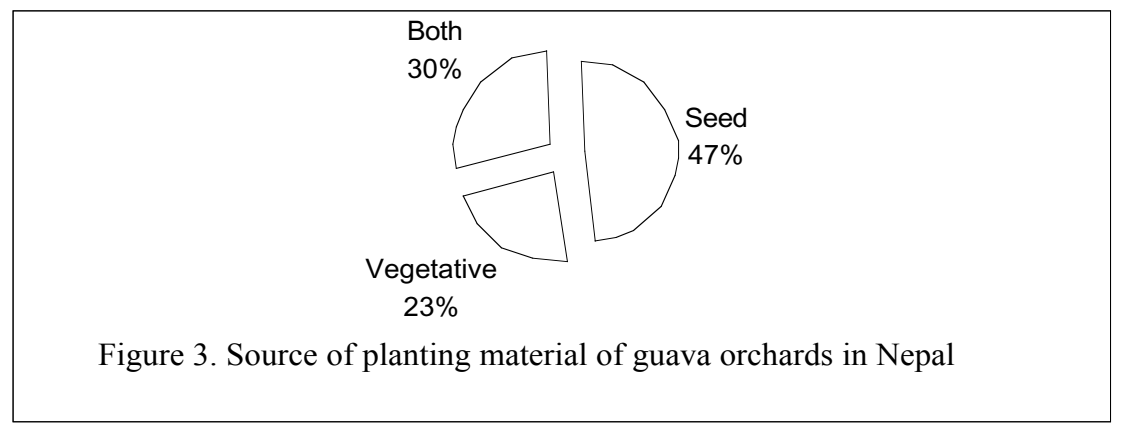

Regarding the varietal status of guava plantain, improved cultivars particularly Indian cultivars, Lucknow49 and Allahabad Safeda dominated in Nepal although 30\% of total guava populations were reported as local (Figure 4). Moreover, mix population of both improved and local cultivars was reported in majority (40\%) of guava orchards (Figure 4). Fruit Development Directorate has been recommending different Indian cultivars in Nepal and the Department of Agriculture is involved in distributing such improved Indian varieties like Lucknow49 through various farms and District Agriculture Development Offices (FDD, 2062 B.S.). Moreover, mix population of both improved and local cultivars was reported in majority $(40 \%)$ of guava orchards (Figure 4). Only improved varieties of guava was recorded in $32 \%$ of orchard in Nepal while about one fourth of the orchards comprised of only the local cultivar. Such preference towards mixing both the local and improved 
cultivars may be due to the intention of the growers to cultivate diverse type of guava cultivars in their orchards.

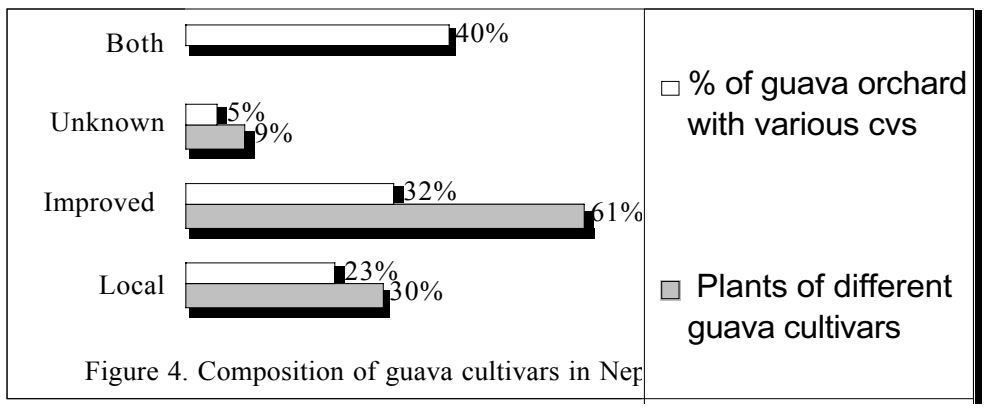

\section{Season of flowering and harvesting}

Variation in the flowering period with ecological regions and cultivars was noticed in guava, commencing on Feb/March and continuing till the month of June/July in Nepal (Figure 5). Such variation regarding the period of flowering may be due to the differences in the environmental condition of that particular guava growing location like altitude and existing temperature. Moreover, the peak period of flowering was April/May followed by Feb/March, May/June, March/April and June/July.

Correspondingly, the harvesting season also varied with different ecological regions and cultivars. The main harvesting period was reported as September although it started in July/August and ended by the month of November. Such variation resulted from variation in the flowering period.

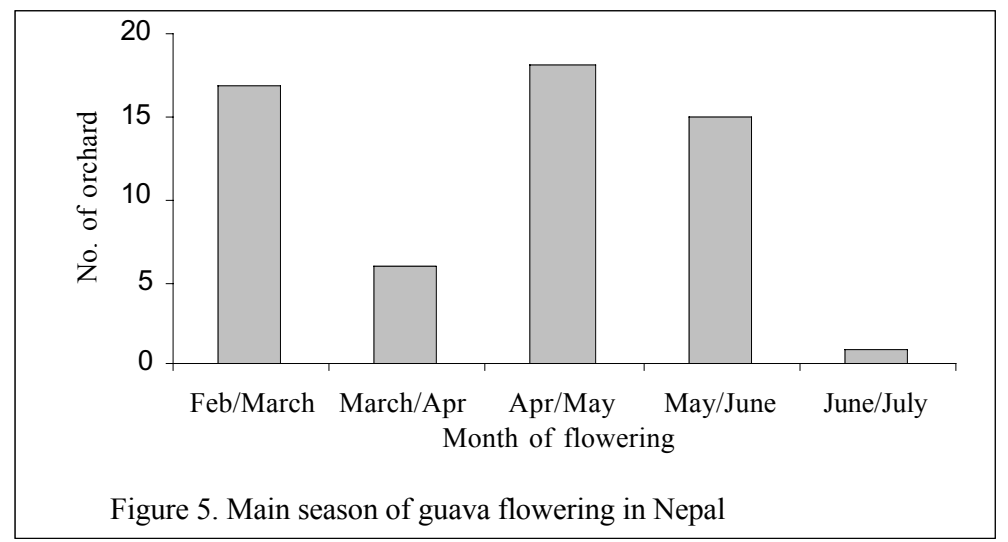

\section{Production problem of guava growers in Nepal}

Disease and insect pests were observed as the main production constraints of Nepalese guava farming although the orchardists also reported problems related to rat/bird and fruit drop during the survey. Guava wilt was recorded as the number one production problem in majority (52\%) of guava orchards. In $28 \%$ of the guava orchards, fruit canker was observed as the main problem by the growers, whereas only $2 \%$ of them considered fruit drop as major constraint (Figure 6).

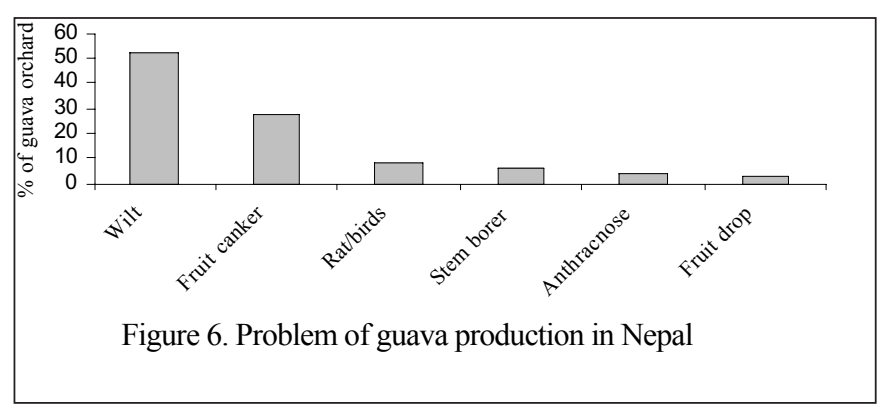




\section{Incidence and management of guava wilt disease}

The incidence of guava wilt was reported from almost all the major guava growing pockets/districts of Nepal although the magnitude of the problem differed. The disease was more severe in 1996 in majority of guava growing areas and its severity increased over time. Budhathoki et al. (1999) pointed out guava wilt as a serious devastating problem in the guava orchards of Nepal and this is a prioritized researchable problem. According to Shoeman and Vos (2003), guava wilt disease is prevalent in almost all guava-growing countries worldwide. In spite of wide and severe occurrence of this disease in Nepal, only $4 \%$ of the guava orchards adopted chemical protection measure (fungicidal spraying) against this malady (Figure 7). In lime and lemon cultivation also, Dhakal et al. (2002) observed that farmers did not care pest management in the orchards, which is mainly due to the lack of suitable technology against this disease and also quick death of tree after the appearance of wilting symptoms.

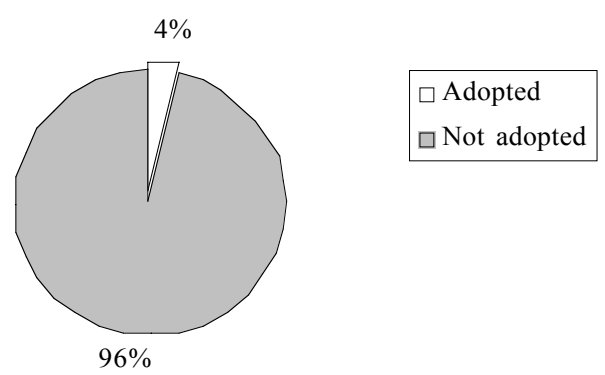

Figure 7. Management practice of guava wilt in Nepal

\section{CONCLUSIONS}

Guava fruit crop covered all the agro-ecological regions of Nepal except the cold temperate region. The production practices, including soil management aspect are very impecunious in the guava orchards of Nepal. Improved cultivars dominated the guava plantation over the local types and these were mostly seedling trees. The availability of Nepalese guava is circumscribed for a period of four months since its flowering and consequent fruiting last for four months. Guava wilt is the foremost biotic constraint affecting production and productivity of guava orchard in Nepal. In spite of the wide and severe occurrence of this malady, appropriate practices recommended/developed elsewhere for controlling the disease are not followed by farmers in almost all of the guava orchards. This is primarily due to the unavailability of suitable and effective control practices and as a consequence, the semi-commercial and commercial scale of guava plantation is unable to meet the domestic demand of fruit.

Considering the above mentioned facts, effective control measures to protect the guava plants from wilt disease is urgently needed to flourish the guava farming in all the ecological regions of Nepal. Nutrient management of orchard soil is also equally important since it is greatly related with health of plant. Moreover, grafting method of propagation should be encouraged because of its various advantages over the sexually propagated plants.

\section{ACKNOWLEDGEMENTS}

The Hill Agriculture Research Project (HARP/DFID) is acknowledged for its funding support to undertake this study. The author is also grateful to all respondents, i.e. concerned District Agriculture Development Offices and guava farmers.

\section{REFERENCES CITED}

APP. 1995. Agriculture perspective plan. National Planning Commission, Singh Durbar, Kathmandu, Nepal. Bose, T.K. and S.K. Mitra.1996. Fruits: tropical and Sub-tropical. Naya Prokash, Calcutta, India. 
Budhathoki, K., M. S. Ghale, S. Ahamad and P. R. Bhurtyal. 1999. Proceedings of the Second National Horticulture Research Workshop, 13-15 May 1998. Nepal Agricultural Research Council, Khumaltar, Lalitpur, Nepal.

Dhakal, D. D., T. P. Gotame, S. Bhattarai and H. N. Bhandari. 2002. Assessment of lime and lemon production in Nepal. J. Inst. Anim. Sci. 23: 49-58.

Fruit Development Directorate. 2062 (B.S.). Horticulture development program. Annual progress report (Nepali) FY 2061/062 B.S. Ministry of Agriculture and Co-operatives, Fruit Development Directorate, Kirtipur, Nepal.

Gautam, D. M. and D. D. Dhakal 1993. Phalphul Tatha Audhogik Bali. Akshyansh Printing Press, Chitwan, Nepal.

MOAC. 2000. Statistical information on Nepalese agriculture 1999/2000. Ministry of Agriculture and Co-operatives, Agri-Business Promotion and Statistics Division, Kathmandu, Nepal.

Sen, P. K. and B. S. Verma. 1954. Studies on the die back disease of guava (Psidium guajava L.): A survey of the incidence of the disease in Thargram area (West Bengal ). 41 $1^{\text {st }}$ Proc Indian Sci. Cong. 258.

Shrestha, G. K. 1998. Fruit development in Nepal: Past, present and future. Technica Concern, Kathmandu, Nepal.

Singh, R. 1969. Fruits. National Book Trust, New Delhi, India.

Yadava, U. L.1996. Guava production in Georgia under cold protection structure. In: J. Janick (ed.) Progress in New Crops. ASHS Press, Arlington. pp. 451-457. 